\title{
Coloured materials in surface water in the sub Arctic Zone: An overview of its formation, properties and environmental changes
}

\author{
Egil T. Gjessing* \\ Harestua, Norway; egil-gjessing@kjemi.uio.no \\ Received 15 January 2013; revised 16 February 2013; accepted 28 February 2013
}

\begin{abstract}
Natural organic matter (NOM) is present in most all surface water. This material is governing all chemical and all biological processes in the aquatic environment, and play a practical role in the drinking water industry From an increasing number of international reports, it is clear that the amount of this coloured matter is increasing in areas of the northern hemisphere. We ask why and we suggest a combination of the following four reasons: 1) Climate (temperature, humidity, nature and frequency of precipitation); 2) Quality and quantity of precipitation; 3) Nature of catchment (topography and geology), and due to changes in local climate and 4) Quality and intensity of global radiation. In the early 1960s, there were reports from Scandinavia about the decline of coloured matter in lakes. The present increase in colour in our lakes and rivers is partly due to the fact that there are less mineral acids in precipitation. However, change in climate, most probably, plays an even more important role in many regions. As a consequence of the temperature increase, there will also be a change in the amount of precipitation and change in its regional and local distribution. As NOM is "produced" in soil and as the development is based on chemical and microbiological decomposition of plant residues, an increased temperature and more rain will extend the "production-area". The global dimming will also have a significant impact on an increased colour in surface water, as less photo-degradation and less bio-available organic matter is resulting. The positive correlation between the colour increase in surface water and the amount of precipitation, may indicate, that there might be a limited amount of water-extractable coloured material in the catchment. It is argued that that
\end{abstract}

*Professor Emeritus. the "production" of the coloured matter will increase and that natural losses, such as "bleaching" etc. will be reduced down flow. Most probably a number of different environmental "mechanisms" are acting simultaneously and/or separately and differently.

Keywords: Water; Colour; NOM; Humus; Drinking Water

\section{INTRODUCTION}

Natural organic matter (NOM) is present in all surface water in the Sub-Arctic region and appears as brownishyellow colour. This organic material is governing all chemical and all biological processes in the aquatic environment. Beside the ecological importance of this coloured material, it also plays a practical role in Water Works, when this type of water is used as drinking water.

There are several practical and hygienic reasons why this coloured organic material is not wanted in our drinking water.

From an increasing number of international reports, it is clear that the amount of this coloured matter is increasing in areas of the northern hemisphere.

The purpose of the present article is to discuss the different environmental "elements" that are involved in this colour-increase phenomenon. This will be of importance for the potential need for upgrading of the existing water works and is important for future planning in the drinking water industry.

\section{THE DEVELOPMENT AND NATURE OF NOM/HUMUS/COLOUR IN WATER}

As it appear from the sketch below, the natural "syntheses" of NOM (humic substances) is based on plant and plant residues in the soil, where carbohydrates, proteins, lignin and tannins are involved.

These basic groups of organic matter are disintegrated 
by chemical oxidation and by microorganisms, using the carbon as the main energy source. The chemical and microbiological activity in the soil is indeed complex. All the reactions are dependant on simple "elements" such as: humidity, content of micro nutrients, $\mathrm{pH}$ and indeed on temperature. All these different "participants", will play a role in the development of the" final product".

With regard to the time aspects, relative to the humification processes, there is apparently not an agreement among the experts. However, this may depend, as indicated above, on climatic element, such as quality and amount of precipitation, and temperature.

According to this illustration, (see Figure 1) the degradation products and metabolic bi-products result in a "poly-hetero-condensation.

According to Kostychev [2], the decomposition and mineralization of organic matter in soil have their maxi- mum at $35^{\circ} \mathrm{C}$ and about $35 \%$ moisture.

Excessive soil moisture apparently promotes the formation of small molecular-size humus because it prevent the removal of condensation by-product (water) and thereby hinders the "growth" of the molecule.

It appears from Figure 2 and Table 1, that the areas with a potential high content of natural organic colour, represent a significant part of our globe. Table 1 suggests that the amount of organic colour is nearly twice as high here as the World's mean value.

Several studies on natural organic matter in water (NOM), performed during the last several decades, inspires Petter Wang (2002) to the illustration shown on Figure 3.

Essentially all micro-nutrition's elements are thus associated with the NOM and may be available for organisms in water (Figure 4).

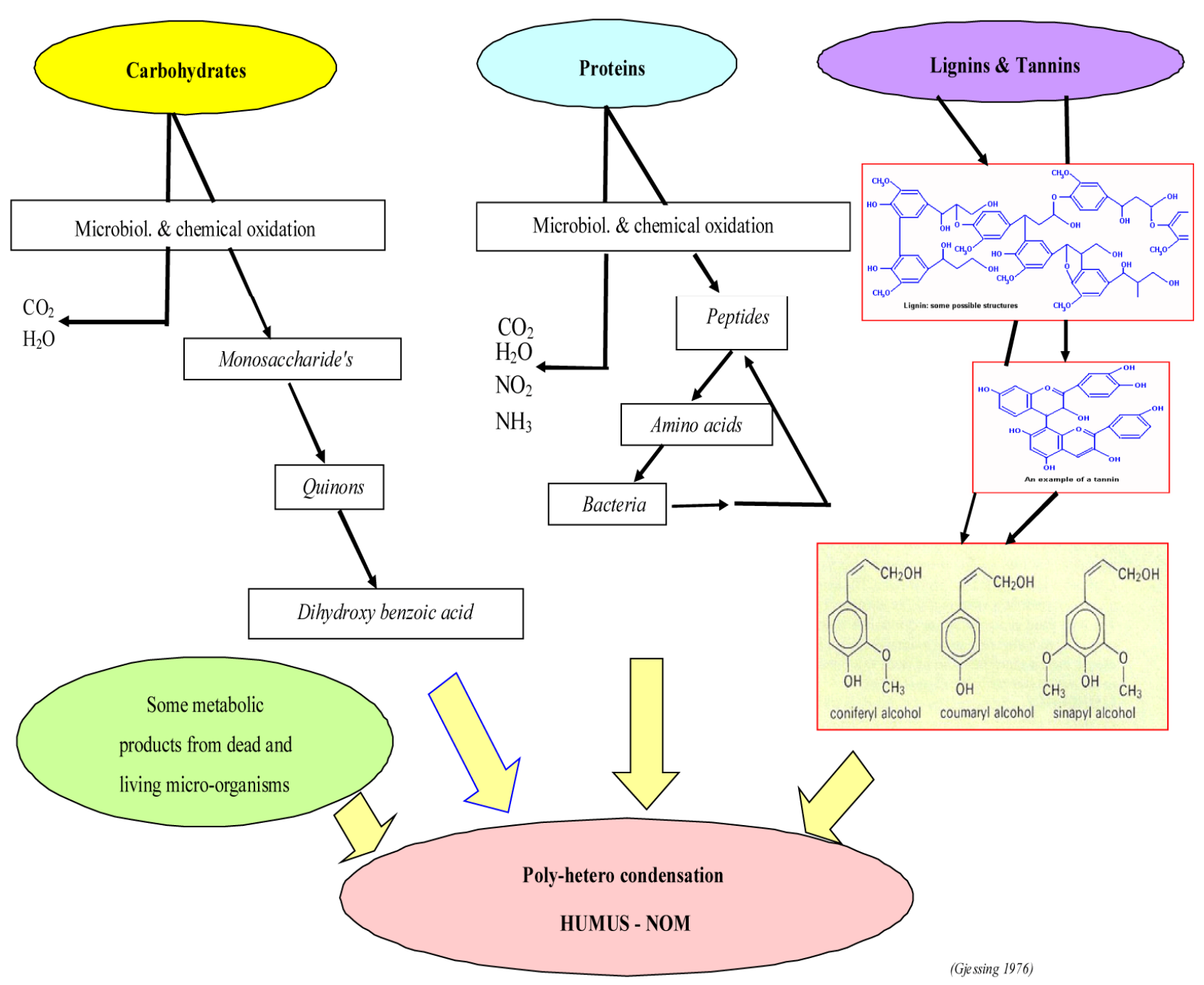

Figure 1. The Humification process [1]. 


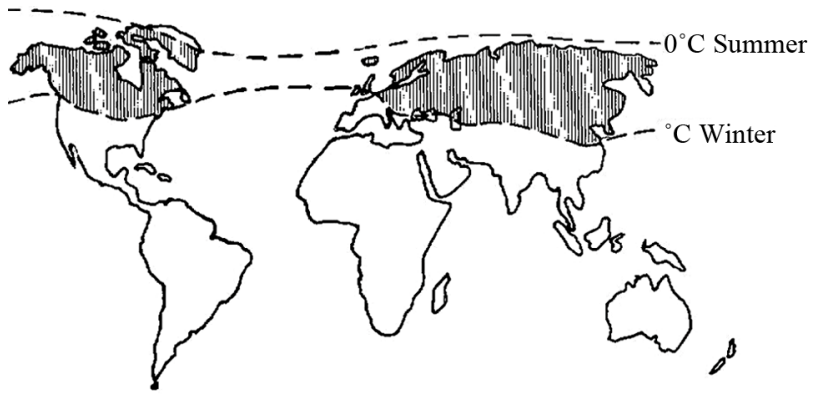

Figure 2. The Sub-Arctic Zone [3].

Table 1. DNOM in surface water in different parts of the world.

\begin{tabular}{cc}
\hline Climatic zone & DNOM $(\mathrm{mg} / \mathrm{L})$ \\
\hline Temperate & 10 \\
Tropical & 12 \\
Sub-Artic & 20 \\
World mean & 11.4 \\
\hline
\end{tabular}

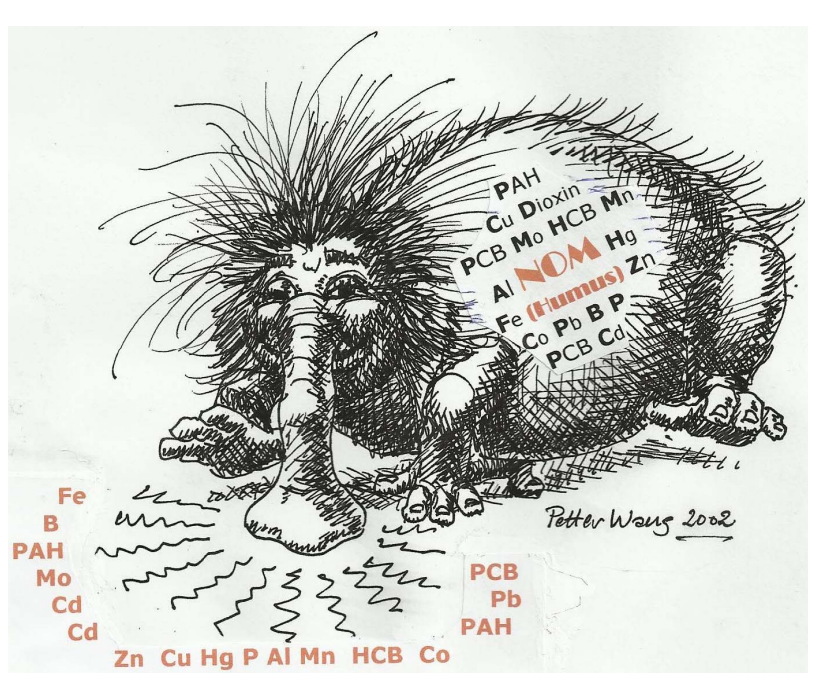

Figure 3. "The Humus Animal" (Petter Wang 2002) ${ }^{1}$.

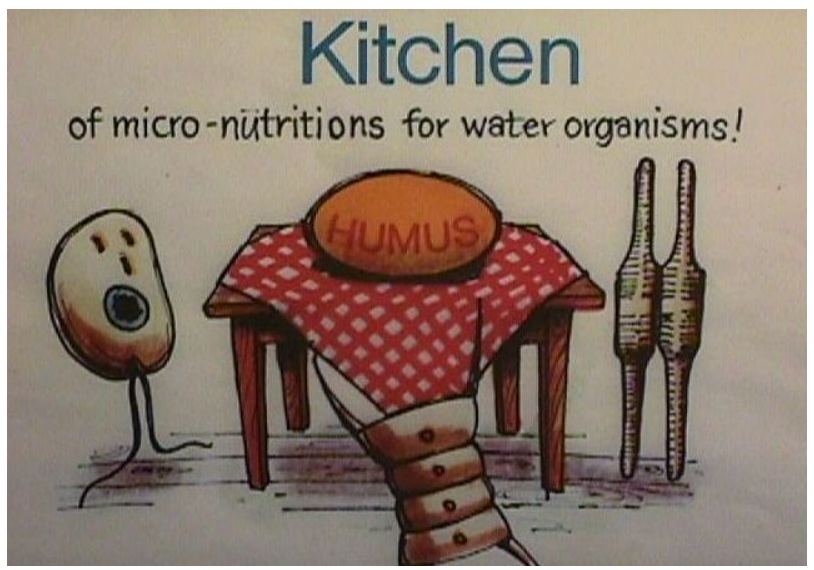

Figure 4. Micro-nutrition's elements are a need for all organisms in water (Petter Wang 2002) ${ }^{1}$.

1petter.wang@fredfiber.net
Toxic elements such as mercury, copper, lead and cadmium are coupled with NOM in such a way that their toxicity may be reduced.

Increased dystrophy reduces the photosynthesis and the photolytic processes in water. This is illustrated on Figure 5.

All processes in nature will be governed by at leased the following five "factors": temperature, water, $\mathrm{pH}$, access to micronutrient and light Accordingly, the prognosis will be, that the content and the quality of NOM in surface water will change with the change of climate, quality of precipitation $(\mathrm{pH}$ and nutrient, such as $\mathrm{N}$ and black carbon $[\mathrm{BC}]$ ). Global radiation (quality and quantity) will also play a role.

Many years ago, in the early 1960s, there were several reports from Sweden about an increasing number of "clear water lakes". Namely a decrease of colour! At that time, professor Svante Oden and several colleagues, also from Sweden, were able to show an increase of the acidity of precipitation the Nordic Countries.

During the following years, environmental scientists in Norway and Sweden suggested that the decrease of the colour of the surface water (increasing number of "clear

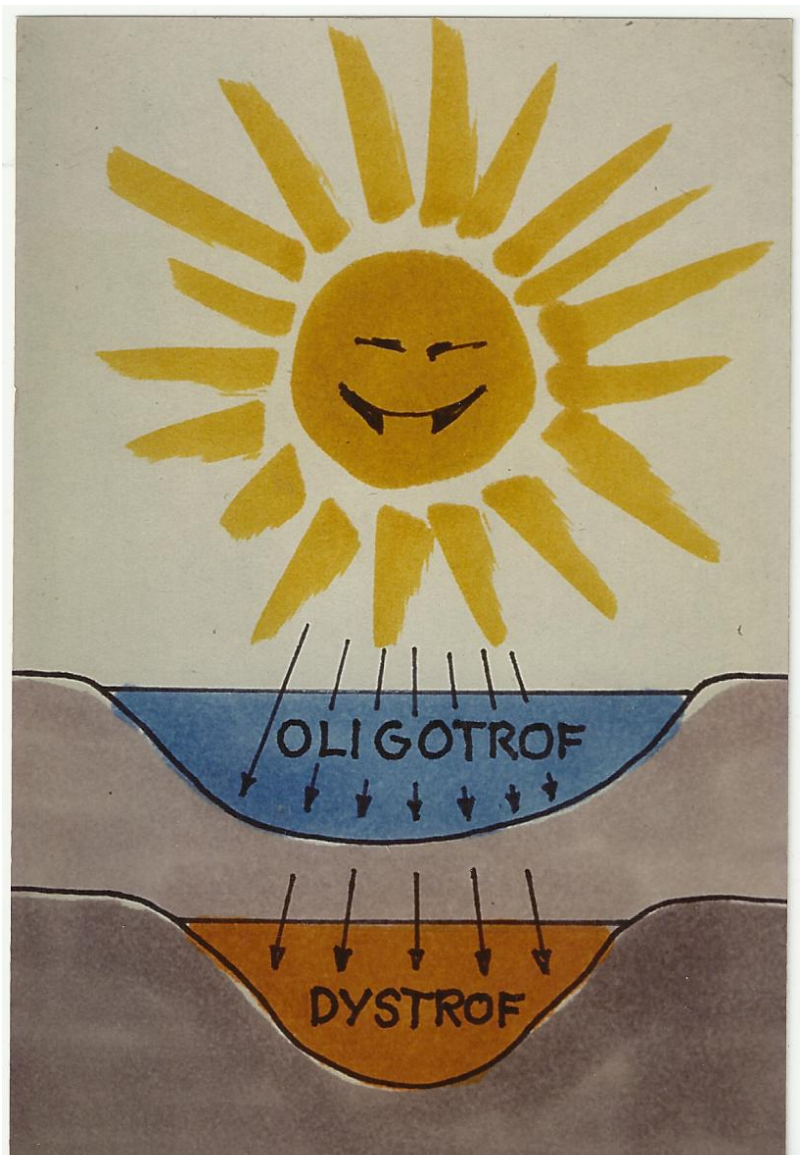

Figure 5. The consequence of a colour-increase is less light and reduced photosynthesis in water (Petter Wang 2002) ${ }^{1}$. 
water lakes") could be explained by acid rain. (This was later confirmed by corresponding experts in Norway and elsewhere in the world).

The four major reasons for why acid rain reduces the colour in surface water are:

1) Reduces microbiological activity in the soil where the humification process takes place (Figure 1).

2) Increased adsorption of the coloured organic matter to mineral surfaces in soils and in the water course (see Table 1 and Figure 6).

3) Colour decreases with decreasing pH (Figure 7).

4) Adsorption of the matter onto Al flocks (Figure 8).

\section{NATURAL QUALITY CHANGES OF NATURAL ORGANIC COLOUR IN WATER}

When the water extractable NOM/Colour in the soil, where it is "synthesised", flows into the aqua- sphere, it will be exposed to another environment. The matter will be exposed to: light, air mineral surfaces and a new set of

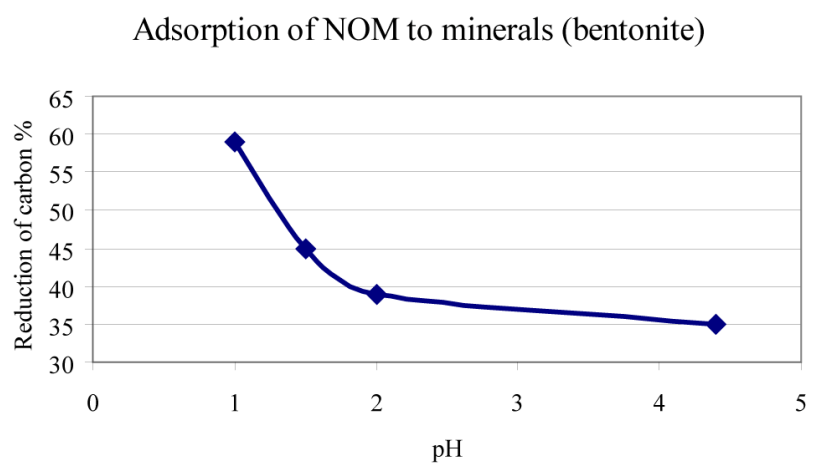

Figure 6. Adsorption of DNOM to Wyoming Bentonite at different $\mathrm{pH}[1]$.

Colour related to $\mathrm{pH}$

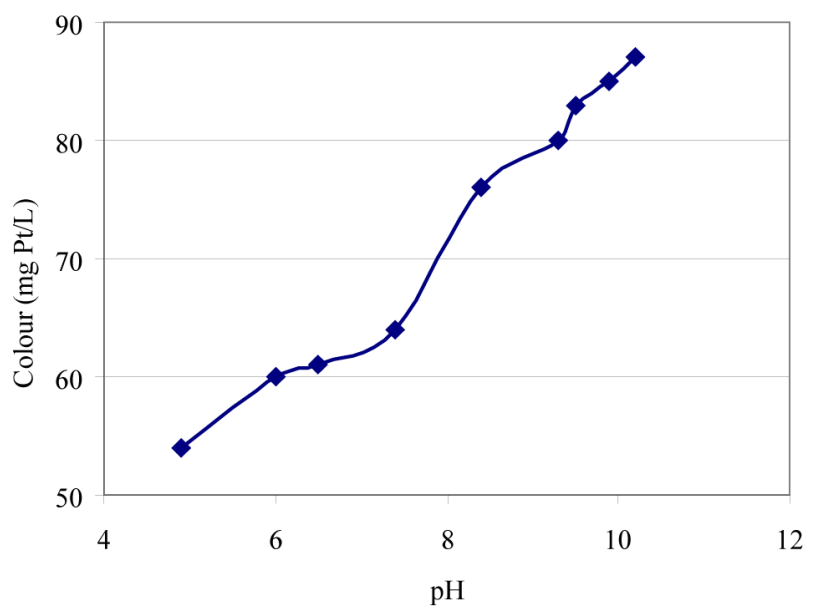

Figure 7. Change of colour with $\mathrm{pH}[\mathrm{HCl}$ and $\mathrm{NaOH}$ was used] [11]. microorganisms. This coloured natural organic matter will get contact with vegetation, in the brook bed, rivers and lakes. All these new environmental "elements" will have an impact on the nature of the NOM.

Some studies performed many years ago, illustrate the natural changes of colour in a water course.

The water course of Trehorningen (Baerum near Oslo, Norway) consist of 4 lakes as illustrated on Figure 9 [4].

Several decades ago, samples were taken from the outlets and inlets of these lakes.

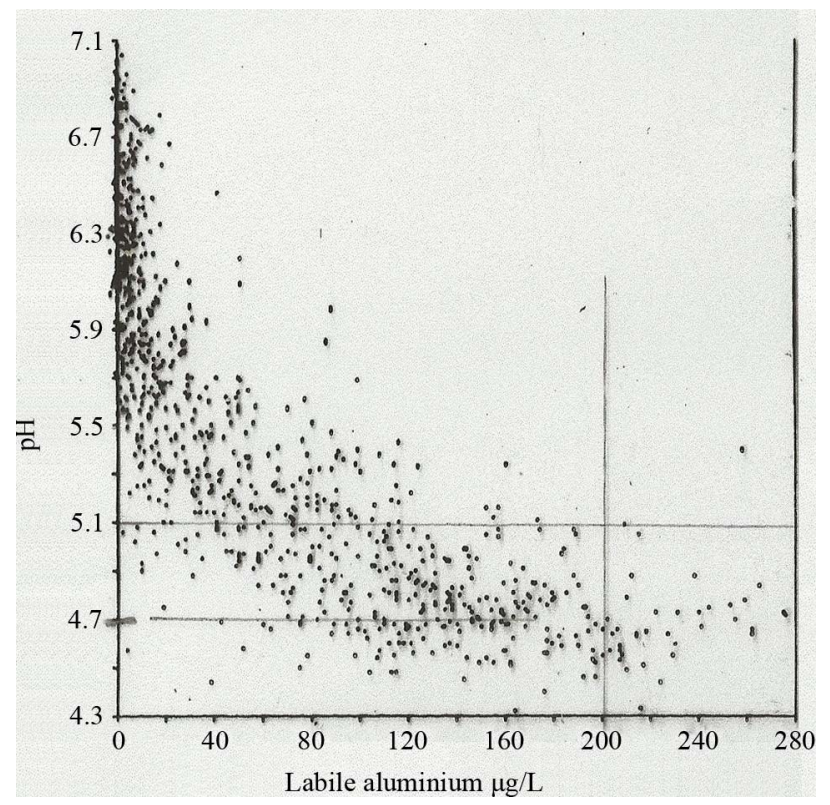

Figure 8. $\mathrm{pH}$ and labile $\mathrm{Al}$ are strongly correlated in 1005 lakes in Norway [16].

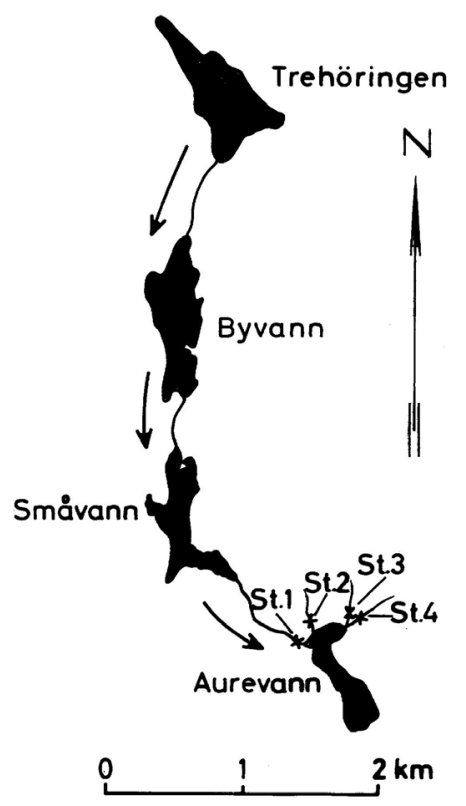

Figure 9. The water course of Trehorningen (Baerum, Norway) [4]. 
It appears from Figure 10, that there is a colour decrease down-stream; in the lakes and in the rivers, inbetween the lakes (NB! Lake Aurevann is a dammed-up drinking water source, therefore, the increasing colour!).

The colour decrease in the three upper lakes in this study, correlates well with the theoretical retention time for the water This appears from Figure 11. According to these studies the colour reduction in lakes is in the range of 4 colour units per month of storage [4].

Global radiation, in particular the short wave radiation, does have a bleaching effect on the colour in surface water.

Laboratory experiments, with water from the Trehorningen region, and available data on local radiation, suggest that about $20 \%$ of this observed colour reduction is due to global radiation [5].

The impact of global radiation on quality of surface water is most probably under-estimated, particularly here in the northern hemisphere. It is well known that short waved radiation of NOM, makes the organic matter more accessible to microorganisms. Several recent studies show that short wave radiation of DNCOM (Dissolved Natural Coloured Organic Matter) may result in significant changes in important properties of this matter in waterworks [6] The indirect effect of radiation on the "removal" of colour in the lakes should here also be emphasised.

With regard to colour reduction in the streams between the lakes (Figure 10), detailed studies in smaller water systems in the same location, suggest that the mechanisms may be different from than that of the lake.

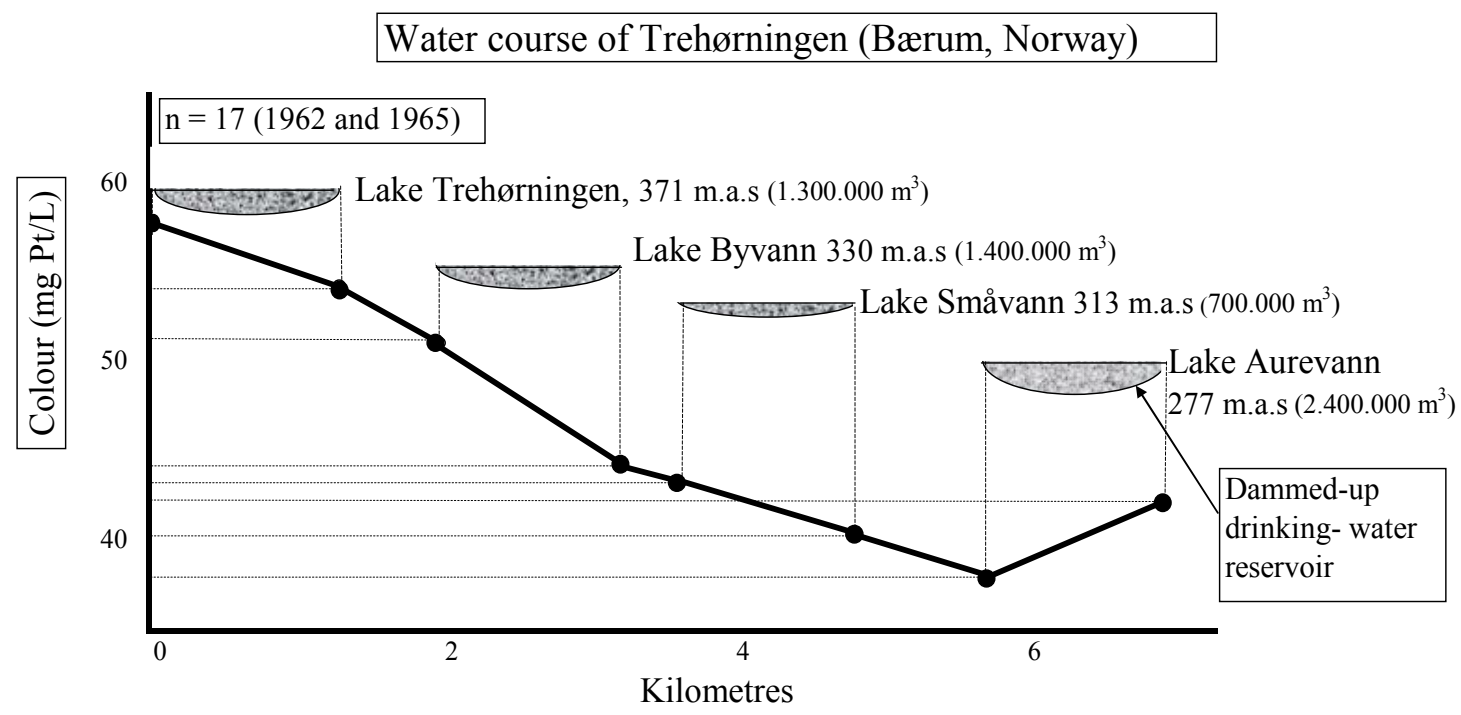

Figure 10. Colour in water downstream the water course of Trehorningen (Baerum, Norway). Samples are taken from outlets and inlets of these lakes through 1962 and 1965 [4].

Reduction of colour in lakes

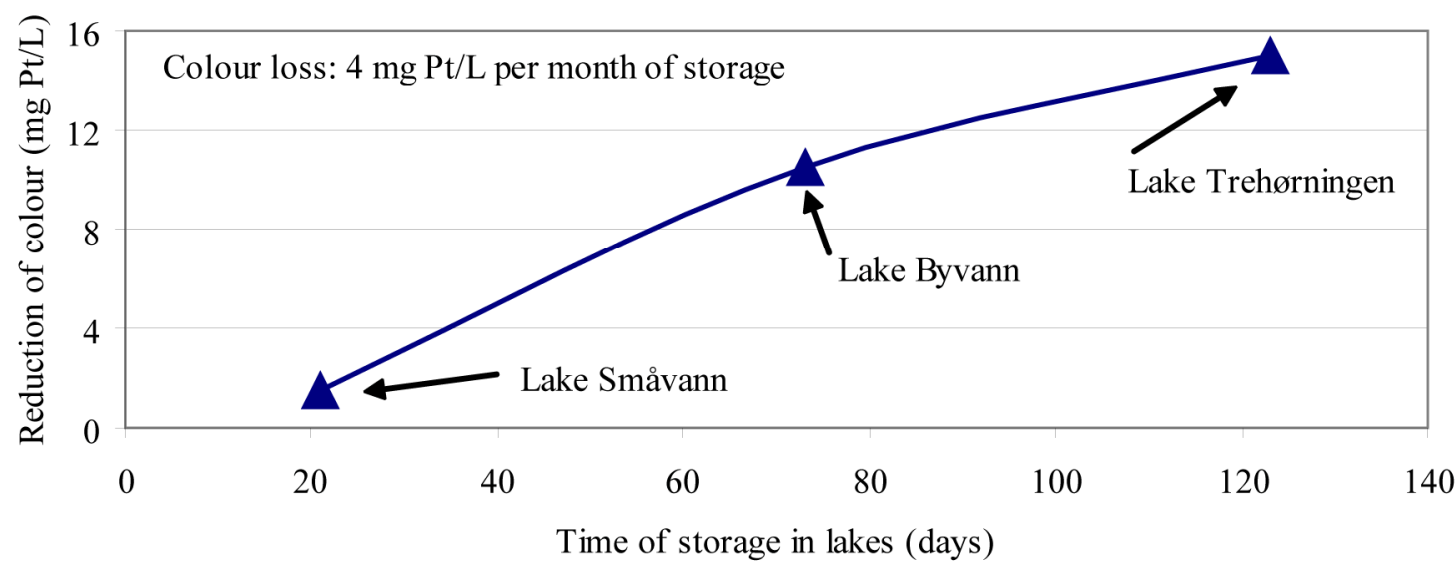

Figure 11. Reduction of colour in lakes (see Figure 9). Colour in the inlets and outlets was measured through 1962 and through 1965. (Number of observations: [Smavann and Byvann: $n=17$; Trehorningen; $n=4]$ ). The colour loss is related to theoretical retention time in the lakes [4]. 
Samples were taken from a brook, originating from a tarn (Hellerudmyre $)^{2}$, through two periods in the early 1960 s.

Simultaneously samples were collected 800 metres further down in the same brook (elevation differences about $120 \mathrm{~m}$ ). The results given in Table 2, show the loss of colour and organic matter and change of quality on this short flow distance, Results from some laboratory experiments, where water from this brook (upper sampling station) is re-circulated in a 30-angel elevated, 2-m-long gutter, which was filled with either crushed stone from this location or crushed inert glass, may suggest that the rate of the water flow has in impact on the result: Higher flow, shorter contact time in the brook and less colour loss [7].

Even though these are simple, laboratory experiments, it could be pointed out that short wave UV-radiation partly oxidise the colour and partly makes it more accessible to adsorption to the mineral surfaces. The short wave UV-radiation ( $\mathrm{Hg}$ lamp) is believed also to depress the micro-biological activity in the gutter!

Molecular size experiments (both related to the brook studies and to the laboratory experiments) suggest that the high molecular weight fractions, in particular, are lost (Brook studies: MW > 5000; reduced with 67\%. MW < 5000 reduced with $38 \%$ ).

Laboratory experiments: $\mathrm{MW}>5000$, reduced with $38 \%$. MW $<5000$, reduced with $12 \%$ [8].

\section{PROPERTIES OF NATURAL ORGANIC COLOUR IN WATER}

\subsection{Recalcitrance}

In general the natural coloured matter in water (humic substance, NOM) is considered to be rather stable. However, as illustrated above, physical, chemical and micro biological changes are natural. In general, therefore, it should be emphasised that the BOD (biological oxygen demand) is low.

\subsection{Solubility}

The matter is dissolved water as complex macromolecules. The water solubility will to some extent differ with content of dissolved salt in the water (conductivity), but more important is the role that $\mathrm{pH}$ play on the solubility and indeed the properties in general. (Please note the classical definition of Humic Acid, Fulvic Acid etc) [9].

\subsection{Charge}

These organic macromolecules have under natural conditions a net negative charge; the coloured matter act as anione [Humus anion: $3.5 \mathrm{meq} / \mathrm{mg}$ DOC]. However, the negative charge will differ with $\mathrm{pH}$.

It will appear from Table 3 that as $\mathrm{pH}$ decreases the negative charge of the colour macromolecule will also decrease.

\subsection{Adsorbability}

Under natural conditions the matter will only to a small extent adsorb to physical surfaces. However, again, $\mathrm{pH}$ plays a role here. Figure 12 illustrates an experiment where the adsorption of natural colour to mineral (Bentonite) as a function of $\mathrm{pH}$, is studied.

\subsection{Absorbability}

This dissolved natural brownish yellow coloured organic matter absorb light. In water from the same location there will in general be a very good correlation between colour (absorption measured at $420 \mathrm{~nm}$ ) and DOC and an even better relationship between colour and UVabsorption $\left(\mathrm{A}_{420 \mathrm{~nm}}\right)$. Spectrophotometer measurements are, therefore, widely used as a simple mean to estimate the content of organic matter in water. Please note, however, that that the colour as such do change with $\mathrm{pH}$. This appears from the results given at Figure 7 [11].

\subsection{Photosensitivity}

Sunlight has in impact on the nature and the amount of coloured material in surface water (see above). The wavelength of the global irradiation in concern in the present publication is wavelength above UV-A (UV-A > $320 \mathrm{~nm}$ ) It should be mentioned at this point that the intensity of this global irradiation and to some extent the quality do change with altitude.

Table 2. Mean values of a brook in Baerum (near Oslo, Norway): 18 samples taken in 1962 and 1963.

\begin{tabular}{|c|c|c|c|c|c|c|c|}
\hline & $\begin{array}{l}\text { Flow } \\
\text { L/sec. }\end{array}$ & $\begin{array}{c}\text { Colour } \\
\mathrm{mg} \mathrm{Pt} / \mathrm{L}\end{array}$ & $\begin{array}{c}\mathrm{DOC}^{\mathrm{b}} \\
\mathrm{mg} \mathrm{C} / \mathrm{L}\end{array}$ & $\begin{array}{c}\text { Iron } \\
\mathrm{g} \mathrm{Fe} / \mathrm{L}\end{array}$ & $\mathrm{pH}$ & $\begin{array}{c}\text { Colour/ } \\
\text { DOC }\end{array}$ & $\begin{array}{c}\text { Colour/ } \\
\mathrm{Fe}\end{array}$ \\
\hline Brook from Hellerudmyra outlet tarn ${ }^{a}$ & 1.0 & 132 & 12.4 & 334 & 4.7 & 10.6 & 0.40 \\
\hline $800 \mathrm{~m}$ down flow (eleva.dif. $120 \mathrm{~m}$ ) & 2.2 & 51 & 5.6 & 149 & 5.1 & 9.1 & 0.34 \\
\hline$\%$ loss & & 61 & 55 & 55 & & & \\
\hline
\end{tabular}

${ }^{\mathrm{a}}$ This is the location on which IHSSs Nordic Humic and Fulvic Acid are based; ${ }^{\mathrm{b}} \mathrm{DOC}=\mathrm{COD} / 2.5-0.75$.

${ }^{2}$ This is the location on which IHSSs Nordic Humic and Fulvic Acid are based (International Humic Substances Society). 
Table 3. Per cent colour organic matter that will be electrical neutral in the given $\mathrm{pH}$-range ${ }^{*}[10]$.

\begin{tabular}{cccc}
\hline \multicolumn{4}{c}{$\mathrm{pH}-$ range } \\
\hline $1.25-1.50$ & $1.50-1.75$ & $1.75-2.00$ & $2.00-12$ \\
$18 \%$ & $52 \%$ & $12 \%$ & $18 \%$ \\
\hline
\end{tabular}

*Isoelectric Focusing. Related to Table 3: The NOM (Humus) have amphyprotic properties. The Isoelectric Focuing Technique (IEF), separate the NOM according to isoelectric point. The NOM sample is mixed with different amino acids and different organic and inorganic acids. This is filed into an "Iso-electrical focusing column"-When voltage is applied to the electrodes on both ends of a coloumn containing the mixture, a vertical $\mathrm{pH}$ gradient is developed and the NOM migrate until they reach a $\mathrm{pH}$-zone where they are uncharged [10].

Reduction of colour in artificial streams

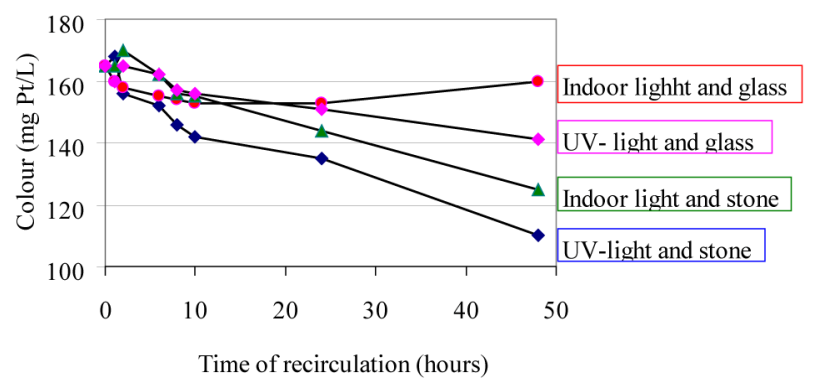

Figure 12. Water from Brook Hellerudmyra (see Table 2). Water is re-circulated in a $30^{\circ}$ angel-elevated, $2 \mathrm{~m}$ long gutter. This gutter was filled with either crushed stone from the location or crushed glass. The experiment was performed with and without UV-radiation (Hg-lamp) [7].

Even though the present topic is related to the natural environment, I include here some aspects related to natural coloured material and UV-C, because the concern related to the present environmental changes is of importance for practical problems affecting the drinking water industry. When Rook in the early 1970s [12] reported that chlorination of coloured water developed chloroform in drinking water, UV-C disinfection became an important alternative.

However, even though UV-C is an effective method to kill bacteria, viruses and parasites, the treatment does result in a change in bioavailability of the coloured matter in the water. This change in the quality of the DOM showed to give more bioactive material in the water. Depending on the "UV-dose", the resulting "product" acts as an algaecide [13] or a bactericide [14].

Recently it has been demonstrated that, after UV-irradiation of NOM, specific bacterial members are well adapted to low $\mathrm{pH}$, high concentration of low molecular weight DOC and oxidative stress and, therefore, thrive well after the UV-treatment [15]. This may have consequences for the drinking water quality during transport from the treatment plant to the consumer.

\subsection{Molecular Weight Distribution}

The size of these complex macromolecules does indeed change with time of storage in lakes and rivers and with a number of environmental "factors", such as $\mathrm{pH}$ [11].

\section{ENVIRONMENTAL DEVELOPMENT IN THE 1970s}

An increased acidity of precipitation was first reported in 1958, by Evil Gorham. It was "re-discovered" in the early 1960s by Svante Oden from Sweden.

During a court hearing in Norway in 1965, a hearing related to a dramatic decline in the inland fish-catch in a lucrative Norwegian salmon river, acid rain was mentioned for the third time. Based on some intensive river quality surveys, in the southernmost part Norway, showing significant acidification of major river in this part of Norway, an inter-dispensary research project was established in 1972.

Soil, forest, water and fish were the major "objects" in these studies (the SNSF-Project).

The results of some studies of soil water chemistry, given in Table 4, demonstrate the soil-acidificationproblem; more than a tripling of $\mathrm{H}^{+}$-concentration.

The results from this, eventually international research project, revealed, that, besides the direct bio-toxic effect of $\mathrm{H}^{+}$in water, the acid rain, resulted in an increase in dissolved $\mathrm{Al}$ in water had also indeed a significant negative bio-effect.

The relation between $\mathrm{Al}$ and $\mathrm{pH}$ is illustrated on Figure 8.

Finally, in relation to the present topic, the development of natural organic colour in soil (and water) it is relevant to emphasise the importance of micro-organisms.

The results on Figure 13 illustrate the impact of $\mathrm{pH}$ on the disintegration of leaves.

During the following decades, the monitoring of water quality worldwide and the knowledge about the quality and fate of harmful environmental elements, have indeed increased.

The cleaning of the combustion product, world-wide,

Table 4. Change of acidity in soil in Rondane (Norway) between the $1940 \mathrm{~s}^{*}$ and 1984 .

\begin{tabular}{ccccc}
\hline Depth & \multicolumn{2}{c}{ Mean pH } & \multicolumn{2}{c}{ Mean $\mathrm{H}^{+}$} \\
\hline & $1945^{*}$ & 1984 & $1945^{*}$ & 1984 \\
\hline $\mathrm{A}_{0}$ & 4.37 & 4.04 & 43 & 91 \\
$\mathrm{~A} 2$ & 4.92 & 4.34 & 12 & 46 \\
$\mathrm{Bh}$ & 5.14 & 4.61 & 7 & 25 \\
$\mathrm{Bf}$ & 5.49 & 4.75 & 3 & 18 \\
$\mathrm{C}$ & 5.69 & 4.84 & 2 & 14 \\
\hline
\end{tabular}

*1942-1949. 

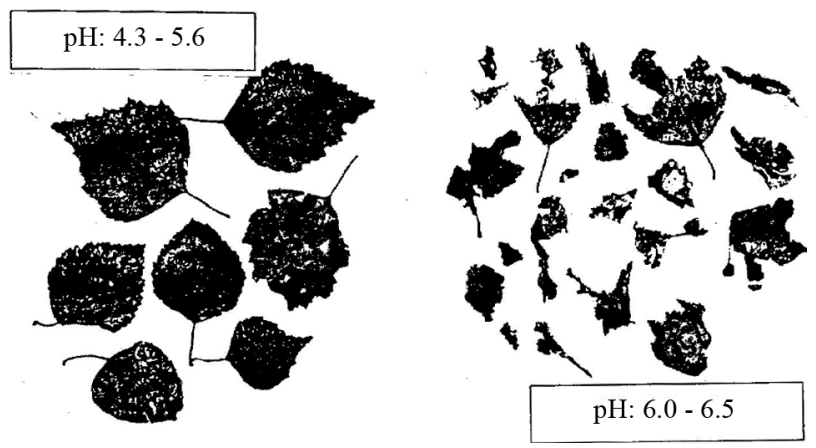

Figure 13. Birch leaves from litterbags that have been left for one year in acid waters ( $\mathrm{pH} 4.3$ - 5.6) [weight loss: 46\%] compared to leaves in more neutral waters ( $\mathrm{pH} 6.0$ - 6.5) [weight loss: 52\%] in southern Norway [17].

Table 5. Change in quality of surface water in Norway between the mid 1980s and the mid 1990s. Unit: $\mu$ eq/L.

\begin{tabular}{cccccccc}
\hline Norway & Number & \multicolumn{2}{c}{$\mathrm{SO}_{4}$} & \multicolumn{2}{c}{$\mathrm{H}^{+}$} & \multicolumn{2}{c}{$\mathrm{Al}$ (inorg.) } \\
\hline & of lakes & 1986 & 1995 & 1986 & 1995 & 1986 & 1995 \\
\hline East & 65 & 73 & 50 & 3.6 & 2.2 & 42 & 28 \\
South & 189 & 60 & 36 & 15.1 & 10.7 & 112 & 64 \\
West & 94 & 30 & 23 & 5.8 & 4.1 & 22 & 15 \\
Mid & 59 & 16 & 12 & 5.8 & 0.7 & 4 & 1 \\
North & 78 & 47 & 42 & 0.3 & 0.3 & 0 & 0 \\
\hline
\end{tabular}

has resulted in less polluted precipitation relative to particularly $\mathrm{H}_{2} \mathrm{SO}_{4}$ (Table 5).

A remarkable consequence of this reduction in $\mathrm{H}_{2} \mathrm{SO}_{4}$, is an increase in the salmon catch in many rivers in the effected regions of Norway.

The monitoring of the surface water quality has also revealed an increase in the colour in many areas in the northern hemisphere. This finding was first reported by Forsberg and Petersen in Sweden in the late 1980s [18].

During the last decades there have been an increased number of reports on an increasing colour in surface water in the sub-Arctic Zone. An example is illustrated in Figure 14.

In general the phenomena of an increase of colour in surface water, apparently started most places, in the mid 1970s.

\section{WHY DOES THE COLOUR INCREASE?}

The impact of climate change on Dissolved Natural Coloured Organic Matter (DNCOM) is believed to mainly be related to temperature, to the amount and quality of precipitation and to global irradiation.

\subsection{Temperature Increase}

- Increase in general growth;

- Change in quality of vegetation;
Colour [Farris. South East Norway]

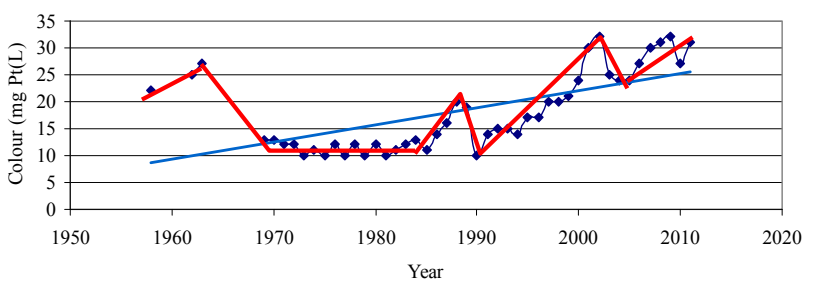

Figure 14. Colour in Lake Farris during the last 50 years.

- More litter;

- Higher rate of decomposition;

- Increase in biochemical activity.

During the last several decades, the tree-line has visibly retreated up-hill and so has also the nature of the

vegetation. It appears from Figure 1, illustrating the biochemical processes in soil, that a change in the "input" may have an impact on the quality of the final product. Likewise an increased temperature will result in a higher rate of decomposition of dead plant material and indeed increase and change the quality of the biochemical activity.

\subsection{Change of Amount of Precipitation}

- Expansion of peat-land area;

- Increased humidity in the soil (favouring smaller molecules);

- More (DNCOM) extracted from soil into water;

- Shorter time of storage of water down-flow.

Reports from the international community show an increase in both the amount and the regional distribution of precipitation.

An increase in precipitation will expand the peaty-land area and consequently increase both the production of and the water extraction of DNOCM.

Another important consequence of more water is shorter retention in the catchment area.

A shorter time of storage in both the terrestrial and aquatic phase, will also, as demonstrated above, have an impact on the nature and the amount of DNOCM. There will be a shorter time for chemical, biochemical and photochemical reactions.

\subsection{Change of Quality of Precipitation}

- Increased $\mathrm{pH}$;

- Increase in colour (see Figure 7);

- Increased microbiological activity (in soil and water) \{see Figure 13\};

- Reduced S/N-ratio;

- Less sulphur (S) in DNCOM;

- Increase in BC (Black Carbon).

The impact of the concentration of $\mathrm{H}^{+}$on all processes 
in life is remarkable. It is also remarkable to notice that it is only a few decades ago, since we realized that the quality of precipitation had to be accounted for relative to the quality of water. Here we will limit our discussion to $\mathrm{pH}$ in rain and snow, except for one relevant observation regarding cations in rain and snow and exchange of $\mathrm{H}^{+}$.

It appears from Figure 15 that cations in precipitation will decrease $\mathrm{pH}$ in soil and water.

Regarding polluted precipitation and quality of DNCOM, it is first of all the mineral acids $\mathrm{H}_{2} \mathrm{SO}_{4}$ and $\mathrm{HNO}_{3}$ that will be included here.

The direct effect of increased $\mathrm{pH}$ on colour (Figure 7), on molecular size (Figure 16) and on charge (Table 3)

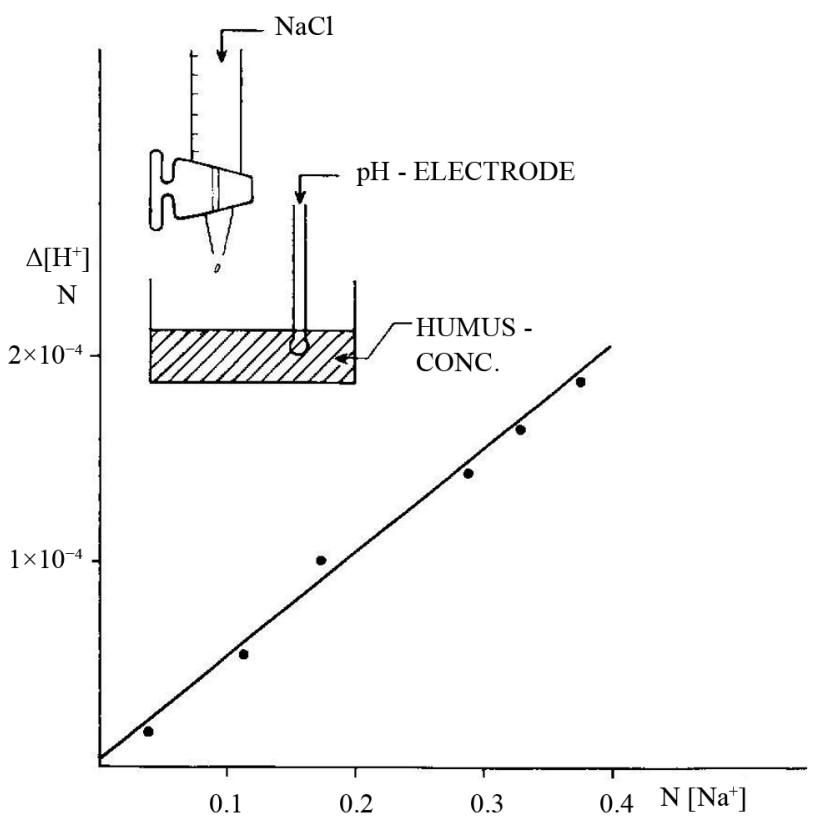

Figure 15. DNCOM acts as a cation exchanger [19].

High molecular weight fraction (HMWF) $\%$ of total area

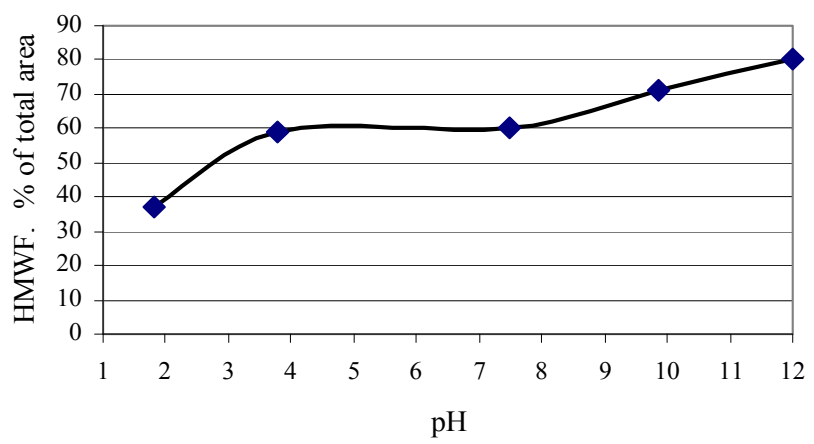

Related to Figure 16, the samples are fractionated on. Sephadex G-25 gel. Each point on the figure, is the mean value of $4-12$ different fractionations. The following chemicals were used to adjust the salt content and $\mathrm{pH}: \mathrm{NaCl}$, $\mathrm{Na}_{2} \mathrm{SO}_{4}, \mathrm{HCl}, \mathrm{NH}_{3}, \mathrm{H}_{2} \mathrm{SO}_{4}, \mathrm{NaOH}$.

Figure 16. Effect of $\mathrm{pH}$ on the molecular size of coloured organic matter in water [11]. will, as stated before, point in the direction of increased colour in water.

The reduction of mineral acids in precipitation, particular sulphuric acid, will, in addition to the impact on the micro-biological activity (also in soil) possibly result in a less sulphur "imbedded" in DNCOM. The results from some earlier work, where the content of organic sulphur is studied, suggest an effect of $\mathrm{H}_{2} \mathrm{SO}_{4}$ on the composition of the DNCOM. This work suggested 1) "An esterification of the coloured matter"; 2) That the S apparently is connected to the HMWF (high molecular weight fraction) and 3) That this sulphur-contained DNCOM apparently acts more toxic to Daphnia and Yearlings of Salmon [20].

In the de-acidification of surface water, $\mathrm{H}_{2} \mathrm{SO}_{4}$ does play the most dominant role.

Because the energy production in the coming decades will still be based on burning, in an N-contained atmosphere $(78 \% \mathrm{~N} ; 21 \% \mathrm{O})$. Consequently the producing of $\mathrm{NO}_{\mathrm{x}}$ will continue to increase. $\left(\mathrm{N}_{2}+\mathrm{O}_{2}+\right.$ heat $\left.=\mathrm{NO}_{\mathrm{x}}\right)$.

In addition to the positive effect that this decrease in the $\mathrm{S} / \mathrm{N}$-ration in the precipitation may have on the biochemical processes in the catchment, the fertilising properties of BC (Black Carbon) should be mentioned. This black matter will also have an impact on the albedo, regarding both regarding snowmelt during spring and on surface temperature in general [21].

\subsection{Change in Global Irradiation}

\subsubsection{Less Light Reaches the Floor}

As a consequence of inreased vegetation in the catchment, less light penetrate down to the surface water and reduces the action of the radiation.

\subsubsection{Global Dimming}

Global dimming is the gradual reduction in the amount of global direct irradiation at the Earth's surface. This was observed for several decades after the start of systematic measurements back in the 1950s [21].

It is thought that global dimming is due the increased presence of aerosol particles in the atmosphere, caused by human action. Aerosols and other particulates absorb solar energy and reflect sunlight back into space. The pollutants can also become nuclei for cloud droplets. Water droplets in clouds coalesce around the particle. Increased pollution causes more particulates and thereby creates clouds consisting of a greater number of small droplets. This means that the same amount of water is spread over more droplets. Small droplets make the clouds more reflective, so that more of the incoming sunlight is reflected back into space and less reaches the Earths surface. The degree of this reduction in irradiation differs in the international reports and indeed it is emphasised that 
there are local differences; such as influences from large cities [22]. Percent wise a decrease in the range of $2 \%$ $4 \%$ per decade is reported. A report from Israel, based on 50 years of operation, conclude with a globally average reduction in irradiation of $0.5 \mathrm{~W} / \mathrm{m}^{2}$ per year, equivalent to a reduction of $2.7 \%$ per decade [23].

Relative to colour in water, the importance of photochemical action for the "production" of more accessible food for aquatic organisms should again be emphasised.

\subsubsection{Reduced Bleaching and Photo Degradation}

During the last decades, there has been an increasing awareness of the role that short wave radiation plays for processes in water As pointed out, the DNCOM is rather recalcitrant. However, when exposed to light, photo chemical reactions result in bleaching and probably most important, making the DNCOM more bio-available. Global dimming will alter these processes!

\section{CONCLUDING REMARK}

The ecological role that the Dissolved Natural Coloured Organic Matter (DNCOM), plays in the aquatic environment, is essential.

In the aqua sphere this matter is a result of natural processes in the terrestrial environment, starting with the photosynthesis, involving light, $\mathrm{CO}_{2}$, chlorophyll and nutrients.

For a number of reasons the content of DNCOM in water will depend on the climate: basically temperature and precipitation (humidity), that do govern all ecological processes.

In the late 1980s Forsberg and Petersen [18] observed an increase in colour in lake water in Sweden.

According to their reports, this increasing colour started in the mid 1970s.

As fare as I know, Forsberg and Petersen showed these results for the first time.

Along with this observed increase in colour there was also a decrease in transparency of the water.

During the following few decades' similar reports were published from other regions in the Sub Arctic Zone, suggesting that this may be a world-wide phenomena.

Expert ecologists have basically used the global climatic changes and change in quality of rain and snow as the explanations.

The ecological importance of this change in water quality relates essentially to an increase in the distribution of micro-pollutants in the environment due the complexing ability of this coloured matter ("polluted DNCOM" (see Figures 3 and 4)) and the "dystrophication" of the aquatic environment (less light penetrates the water (see

${ }^{3}$ petter.wang@fredfiber.net

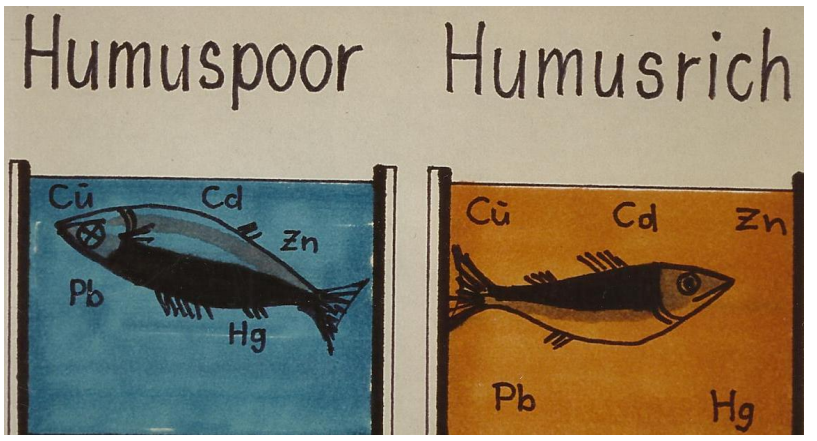

Figure 17. Elements, toxic to aquatic organisms may be complexed to the coloured matter, resulting in reduced action ${ }^{3}$.

\section{Figure 17)).}

However, as always, the direct economical consequences are what trigger further efforts.

During the last $11 / 2$ decades, the NOM in drinking water has received more and more hygienic attention. This is partly due to the "polluted nature" of the coloured material and partly due to microbial transformation of the DNCOM in its increasing distance between the source and the consumer. The drinking water industry needs to know about future investments with regard to colour removal.

Climatic changes involve both short-term and the longterm weather conditions.

In relation to quality of surface water and increase in colour, it is basically:

- temperature,

- amount and quality of precipitation and

- amount and quality of global radiation that have an impact on quality and amount of the matter.

Based on our analysis of available data, based on the prognosis given by experts within climatic changes and based on own accumulated knowledge, I may conclude that the colour in surface water will continue to increase in many areas of the Northern Hemosphere.

\section{REFERENCES}

[1] Gjessing, E.T. (1976) Physical and chemical characteristics of aquatic humus. Ann Arbor Science Publishers Inc., Ann Arbor.

[2] Kostyckev, P.A. (1886) Soil of the chernozem region of Russia. Part I. The formation of chernozem. In: Aleksandrova, L.N., Ed., Study of the Humification of Plant and the Nature of Newly Founded Humic Acid, Soviet Soil Science, 429-437.

[3] Gjessing, E.T. (1980) Water treatment considerationsAquatic humus. In: Smith, D.W., Ed., Proceeding from Post Conference in Alberta, Canada. International Association on Water Pollution Research, Oxford, 95-101.

[4] Gjessing, E.T. and Samdal, J.E. (1968) Humic substances in water and the effect of impoundment. Journal (American Water Works Association), 60, 451-455.

[5] Gjessing, E.T. and Gjerdal, T. (1970) Influence of ultra- 
violet radiation on aquatic humus. Vatten, 26, 144-145.

[6] Paul, A., Dziallas, C., Zwirnmann, E., Gjessing, E.T. and Grossart, H.P. (2012). UV-irradiated freshwater: Impact of Natural Organic Matter (NOM) on quality of organic matter and on bacteria. Aquatic Sciences, 74, 443-454. doi:10.1007/s00027-011-0239-y

[7] Gjessing, E.T. (1970) Reduction of aquatic humus in streams. Vatten, 26, 14-23.

[8] Gjessing, E.T. (1970) Some factors affecting on the stability of aquatic humus. Vatten, 26, 135-143.

[9] Oden, S. (1910) Die Huminsauren Kolloidchem. Beiheft, 11, 75-98.

[10] Gjessing, E.T. and Gjerdahl, T. (1975) Electromobility of aquatic humus. Fractionation by the use of the isoelectric focusing technique. In: Povoledo, D. and Golterman, H.L., Eds., Humic Substances-Their Structure and Function in the Biosphere. Proceedings of an International Meeting, Nieuwersluis, 29-31 May 1972, 43-51.

[11] Gjessing, E.T. (1971) Effects of $\mathrm{pH}$ on the filtration of aquatic humus using gels and membranes. Schweizriche Zeitscherift fur Hydrologie, 33, 592-600.

[12] Rook J.J. (1974) Formation of haloforms during chlorination of natural waters. Water Treatment Examination, 23, 234- 243.

[13] Gjessing, E.T. and Källqvist, T. (1991) Algicidal and chemical effect of u.v.-radiation of water containing humic substances. Water Research, 25, 491-494. doi:10.1016/0043-1354(91)90087-7

[14] Paul, A., Gjessing, E.T., Lønnechen, H. B. and Liltved, H. (2006) Bactericidal effect of water containing natural organic matter (NOM). In: Fritz, H.F. and Abbt-Braun, G., Eds., Humic Substances - Linking Structures to Functions, Proceeding from 13th Meeting of the IHSS, Karlsruhe, 921-924.

[15] Paul, A., Dziallas, C., Zwirnmann, E., Gjessing, E.T. and Grossart, H.P. (2012) UV-irradiated freshwater: Impact of natural organic matter (NOM) on quality of organic matter and on bacteria. Aquatic Sciences, 74, 443-454. doi:10.1007/s00027-011-0239-y

[16] Rosseland, B.O. and Henriksen, A. (1990) Acidification in Norway. Loss of fish population and the 1000-lake survey. Science of The Total Environment, 96, 45-56.

[17] Traaen, T. (1980) Personal communication. Norwegian Institute for Water Research, Oslo.

[18] Forsberg, C. and Petersen, R.C. (1990) A darkening of Swedish lakes due to increased humus input during the last 15 years. Verhandlungen der Internationalen Verein Limnolgie, 24, 289-292.

[19] Gjessing, E.T. and Johannessen, M. (1976) Potential effects of metals in precipitation on the exchangeable humus-hydrogen in soil and surface water. In: Nriagu, J.O., Ed., Environmental Biogeochemistry: Vol. 2. Metal Transfer and Ecological Mass Balances, Ann Arbor Sciences Publishers Inc., Ann Arbor, 557-563.

[20] Gjessing, E.T., Efraimsen, H., Grande, M., Källqvist, T. and Riise, G. (1991) Changes in properties of humic substances by sulphuric acids acidification. In: Baker, R.A., Ed., Organic Substances in Sediments and in Water, Lewis Publishers, Michigan, 89-98.

[21] Wikipedia. www.Wikipediano/

[22] Abakumova, G.M., Feigel, E.M., Russak, V. and Stadnik, V.V. (1996) Evaluation of long-term changes in radiation, cloudiness and surface temperature on the territory of the former Soviet Union. Journal of Climate, 9, 1319-1327. doi:10.1175/1520-0442(1996)009<1319:EOLTCI $>2.0 . C$ $\underline{\mathrm{O} ; 2}$

[23] Stanhill, G. and Cohen, G. (2001) Global dimming: A review of the evidence for a widespread and significant reduction in global reduction with discussion of its probable causes on possible agriculture consequences. Agricultural and Forest Meteorology, 107, 255-278. doi:10.1016/S0168-1923(00)00241-0 